\title{
Economic and Social Condition of the Software Quality Assessment
}

\author{
Katarzyna Lis and Jerzy Olszewski \\ University of Economics Department of Labour and Social Policy, \\ 61-875 Poznań, Al. Niepodległości 10, Poland \\ katarzyna.lis@.ae.poznan.pl, jerzy.olszewski@ae.poznan.pl
}

\begin{abstract}
Issue of the computer software quality has an interdisciplinary nature and it is a subject of research in numerous scientific disciplines, including the software engineering, economics, psychology and ergonomics. Considerations concerning the integration of the subjective factors with the technical parameters in respect of the computer software quality testing are not present in the literature'. Therefore, this Article comprised the results of research on the software quality assessments made by users. This Article includes four parts, which represent: the research methods, the economic conditions connected with the computer software quality assessment, the social conditions and the Summary. The first part of the Article discusses the method of correspondence as well as the typology of the economic and social working conditions that were used to create the correlation model for the computer software assessment. In the second part of the Article the authors discussed the economic conditions for computer software assessment that were qualified to one of the three groups: variables that describe: organizational and technical situation, self assessment of the employee's position in the company and the evaluation of the employment security. Further part of this Article is dedicated to correlation between the social issues and the computer software quality assessment. The four variables: sight affections, monotony of work, work intensiveness as well as the psychophysical affections were classified under a single group titled Employee Health Hazards. This Article is concluded with Summary, where the authors indicated the essentiality of economic and social issues in the computer software quality assessment.
\end{abstract}

Keywords: software quality assessment.

\section{Research Method}

Review of the literature indicated the proposed typology of the economic and social working conditions that was used to create the correlation model for the computer

${ }^{1}$ B. Krawczyń-Bryłka, Psychologiczne aspekty jakości oprogramowania, Informatyka, vol. 1112, 2000, p. 37. 
software assessment (evaluation of characteristics described in ISO 9126) ${ }^{2}$. This model may be used by software developers and company management to find out the reasons of the employees' specific attitude toward implemented software.

With a view to conduct an empirical research, the research methods, including the representative method, sample selection and the method of correspondence analysis were characterized. The method of correspondence analysis was used to examine quality-quantifiable features that constituted both economic and social working conditions and the qualities of the computer software. Additionally, due to nonmeasurable character of qualities pertaining to the software being assessed by the users, the universal unitary scale of relative conditions used to determine the software quality was presented. Characterization of the persons examined according to demographic and social characteristics was required to perform the computer software assessment.

The results of evaluation of economic and social working conditions in concerned companies that were used to determine the employees' attitude and motivation for work are presented here. Six characteristics from the international standard ISO 9126 were adopted to assess the quality of the computer software. These characteristics are: functionality, reliability, usability, performance, modifiability and transferability. Such selection of features allows the computer software users to indicate which properties are essential for the users. For the 162 researched companies the improvement of the software performance would effect in increased financial benefits.

Improvement of transferability and reliability of the computer software would significantly affect the organization of work and the same the acceptance of computerization by the users, who work in the concerned companies.

Determination of how the assessment of computer software is correlated with the economic and social working conditions was demonstrated by means of the model presented in Tabele 1. Relations between particular variables were presented by value of inertias in two-dimensional perception maps that were contained in the matrix. For better visualization of the results the hypsometric scale was used for inertia values of the coordinates configuration. From calculated average inertia values the importance level of relation between the computer software quality assessment and the economic and social working conditions were determined.

Improvement of transferability and reliability of the computer software would significantly affect the organization of work and the same the acceptance of computerization by the users, who work in the concerned companies.

Determination of how the assessment of computer software is correlated with the economic and social working conditions was demonstrated by means of the model presented in Tabele 1.

Relations between particular variables were presented by value of inertias in twodimensional perception maps that were contained in the matrix. For better visualization of the results the hypsometric scale was used for inertia values of the

${ }^{2}$ D. Galin, Software Quality Assurance, Pearson Education Limited, Addison Wesley, London 2004, p. 38. 
Table 1. Relations between the computer software quality assessment and the economic and social working conditions

\begin{tabular}{|c|c|c|c|c|c|c|c|c|c|}
\hline & \multicolumn{6}{|c|}{ Computer Software Qualities } & \multirow{2}{*}{ 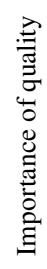 } \\
\hline & & & 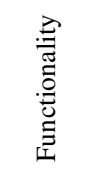 & 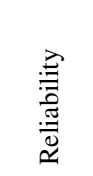 & 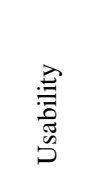 & 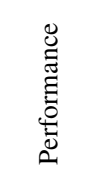 & 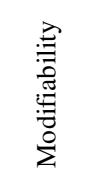 & 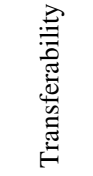 & \\
\hline \multirow{13}{*}{ 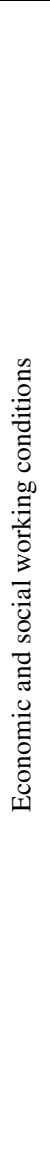 } & \multirow{3}{*}{$\begin{array}{c}\text { Assessment } \\
\text { of } \\
\text { organizational } \\
\text { and economic } \\
\text { condition of } \\
\text { the company } \\
\text { by } \\
\text { respondents }\end{array}$} & $\begin{array}{l}\text { Company } \\
\text { computerization }\end{array}$ & 100,00 & 100,00 & 100,00 & 100,00 & 100,00 & 100,00 & 1 \\
\hline & & $\begin{array}{l}\text { Company's } \\
\text { economic } \\
\text { benefits } \\
\end{array}$ & 94,65 & 96,07 & 90,05 & 80,85 & 92,38 & 94,82 & 7 \\
\hline & & $\begin{array}{l}\text { Organization of } \\
\text { labour }\end{array}$ & 90,83 & 79,14 & 91,00 & 88,53 & 90,65 & 74,40 & 10 \\
\hline & \multirow{5}{*}{$\begin{array}{l}\text { Self- } \\
\text { assessment of } \\
\text { the } \\
\text { employee's } \\
\text { situation in } \\
\text { the company }\end{array}$} & $\begin{array}{l}\text { Satisfaction of } \\
\text { pay }\end{array}$ & 97,20 & 97,70 & 98,78 & 97,44 & 95,42 & 98,94 & 2 \\
\hline & & $\begin{array}{l}\text { Cooperation } \\
\text { between } \\
\text { respondents and } \\
\text { computer staff }\end{array}$ & 99,68 & 92,87 & 97,22 & 82,88 & 99,79 & 99,44 & 3 \\
\hline & & Training quality & 89,65 & 97,73 & 87,63 & 87,99 & 94,58 & 99,48 & 5 \\
\hline & & $\begin{array}{l}\text { Satisfaction of } \\
\text { work }\end{array}$ & 89,78 & 86,88 & 94,49 & 90,79 & 85,52 & 93,58 & 6 \\
\hline & & $\begin{array}{l}\text { Attitude to } \\
\text { computerization }\end{array}$ & 79,26 & 68,58 & 79,93 & 83,67 & 80,14 & 87,42 & 11 \\
\hline & $\begin{array}{c}\text { Evaluation of } \\
\text { the } \\
\text { employment } \\
\text { security }\end{array}$ & $\begin{array}{l}\text { Risk of the job } \\
\text { loss }\end{array}$ & 100,00 & 100,00 & 100,00 & 100,00 & 100,00 & 100,00 & 1 \\
\hline & \multirow{4}{*}{$\begin{array}{c}\text { Evaluation of } \\
\text { health hazard } \\
\text { by } \\
\text { respondents }\end{array}$} & Sight affections & 94,90 & 94,90 & 94,76 & 98,44 & 91,72 & 92,68 & 4 \\
\hline & & $\begin{array}{l}\text { Monotony of } \\
\text { work }\end{array}$ & 93,38 & 92,74 & 92,36 & 84,99 & 95,59 & 82,25 & 7 \\
\hline & & $\begin{array}{l}\text { Intensiveness of } \\
\text { work }\end{array}$ & 91,50 & 90,83 & 96,51 & 88,30 & 81,08 & 85,56 & 8 \\
\hline & & $\begin{array}{l}\text { Psychophysical } \\
\text { affections }\end{array}$ & 96,99 & 82,19 & 93,79 & 84,89 & 95,60 & 79,36 & 9 \\
\hline
\end{tabular}

coordinates configuration. From calculated average inertia values the importance level of relation between the computer software quality assessment and the economic and social working conditions were determined. 


\section{Economic Conditions of the Computer Software Quality Assessment}

Economic conditions of the computer software quality assessment were classified into the three groups: variables that determine: organizational and technical situation, self assessment of the employee's situation in the company and evaluation of the employment security.

The first place, where inertia value is $100 \%$, is taken by the relation between the computer software quality assessment and the importance of computerization for the company (group of the organizational and economic factors) and the evaluation of the job loss risk (employment security). The employees who evaluate the software quality very well are convinced that computerization has a great importance for their company. Computerization in its general meaning stands for development and upgrading of the information system. It contributes to the raise of the company's competitiveness. The company that does not want or is not able to adapt to the market and the conditions related with the economy transformation stops to develop, and in time it loses its ability to satisfy the needs of the environment and its employees, and the same it must be unsuccessful in its operation ${ }^{3}$. That is why the management should take actions to enable satisfying of the needs connected with personal development of the employees. Then, the employees who reach their own development goals would positively associate them with the company's development and computerization.

In the circumstances of the job loss risk due to computerization the employees assess the software quality as bad, while if they are not afraid of losing their jobs their assessment of the software quality would increase. Such correlation may be due to current situation in the labour market. Absence of the job loss risk is for the Polish employees one of the two, next to the pay, most important factors in their careers ${ }^{4}$.

Subsequent second, third, fifth and sixth place belong to conditions for the computer software quality assessment that are included in the group of the self assessment of the employee's situation in the company.

In the second place it is relation between the software quality assessment and the satisfaction of pay. Average inertia in this place is $97.6 \%$. Third place with average inertia $95.3 \%$ is taken by the relation between the computer software quality assessment and the evaluation of the respondents' cooperation with computer staff, which is expressed by the relationship between the superiors and the subordinates, who are the respondents, i.e. subordinates and other employees. Attitude of superiors to all employees should be based on the rule of equality according to the principle of social justice. Average inertia value $92.8 \%$ assigned fifth place for the relation between the computer software quality assessment and the quality of computer training. Rise of qualifications by employees training is helpful in breaking the fear of and reluctance for adaptation to new working conditions and the fear of being moved

3 R. Borowiecki, M. Romanowska, Strategic Information Systems, Centrum Doradztwa i Informacji Delfin sp. z o.o., Warsaw 2001, p. 73.

4 The same, p. 257. 
to another job. Rising of qualifications would affect the employee's sense of his or her own value.

Sixth place with average inertia $91.5 \%$ constitutes the relation between the computer software quality assessment and the evaluation of the satisfaction of work. It may be concluded from the made analysis that this relation is directly proportional. Seventh place with inertia value $90.2 \%$ was reached by the relations between the computer software quality assessment and evaluation of the company's economic profits (variable classified to this group under the title Evaluation of the Organizational and Technical Situation). The same group includes the relation between the computer software quality assessment and the organization of work that took tenth position with the average inertia value of $85.8 \%$. The made analysis indicates that very good quality of the software is identified with improved efficiency of work, and good and rather good quality with fastness and correctness of retrieved data. Average inertia value of $79.8 \%$ gave the last eleventh position to the relation between the computer software quality assessment and the respondents' attitude toward computerization (the group of self assessment of the employee's situation in the company) that is traditionally regarded in the literature as a collection of bad assessment of the software quality and the reason of resistance to the changes in the company.

\section{Social Conditions of the Computer Software Quality Assessment}

Social conditions of the computer software quality assessment were classified to single group - employee's health hazards. This group contains the four variables: sight affections, monotony of work, intensiveness of work and psychophysical affections.

The highest value among the social factors - fourth place in general hierarchy of the average inertia value - $94.6 \%$ - was taken by the relation between the computer software quality assessment and the evaluation of sight affections. Eye fatigue is an essential factor that affects human well-being and psychophysical condition. As it is indicated by the analysis, affections connected with the perception of information by the sight organ affects the computer software quality assessment. The seventh place with the average inertia value of $90.2 \%$ was taken by the relation between the computer software quality assessment and the evaluated monotony of work. The seventh place in the classification went to the variable titled Monotony of Work. Average inertia value of $89.0 \%$ assigned the eighth place to the relation between the computer software quality assessment and the intensiveness of work that is number of tasks performed by the software user. The analysis indicates that the computer software quality is well assessed by the users whose tasks number is adequate and does not exceed their capacities. Average inertia of $88.8 \%$ assigned the ninth place to the relation between the computer software quality assessment and the evaluation of the psychophysical affections that are hazardous for the employee's health. The made analysis indicates that the persons who are anxious and nervous as well as exhausted and weakened have worse assessment of the software quality than the persons with such affections like: painfulness of joints, stiffness and painfulness of wrists. 


\section{Summary}

The developed model demonstrates that the analysis of users may not be based only on their experience and skills, but it must extend over details concerning their economic and social working conditions. The research confirmed that the relation between the computer software quality assessment and the economic and social working conditions existed in the concerned companies. The research allowed developing of the model of correlation between the computer software quality assessment and the economic and social working conditions. This model represents both cognitive and practical value as it allows the companies that implement information systems to recognize possible risks connected with the absence of acceptance for the software by the users.

\section{References}

1. Borowiecki, R., Romanowska, M.: Strategic Information Systems. In: Centrum Doradztwa i Informacji Delfin sp. z o.o., Warsaw (2001)

2. Galin, D.: Software Quality Assurance. In: Pearson Education Limited, Addison Wesley, London (2004)

3. International Standard ISO/IEC/9126: Information technology - Software product evaluation - Quality characteristics and guidelines for their use, Geneva (1991)

4. Krawczyń-Bryłka, B.: Psychologiczne aspekty jakości oprogramowania, Informatyka, vol. $11-2(2000)$ 